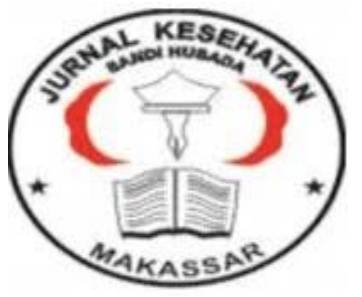

\author{
Jurnal Ilmiah Kesehatan Sandi Husada
}

hhttps://akper-sandikarsa.e-journal.id/JIKSH

Vol 9, No, 1, Juni 2020, pp; 109-115

p-ISSN: 2354-6093 dan e-ISSN: 2654-4563

DOI: $10.35816 /$ jiskh.v10i2.230

\title{
Tingkat Kecanduan Smartphone dan Self Efficacy dengan Prestasi Belajar Mahasiswa Fakultas Kedokteran Universitas Malahayati
}

The Level of Smartphone Addiction and Self Efficacy with Student Achievements in the Faculty of Medicine at Malahayati University

\author{
Beta Gustilawati ${ }^{1}$, Deviani Utami ${ }^{2}$, Supriyati ${ }^{3}$, Achmad Farich ${ }^{4}$ \\ 123 Program Studi Kedokteran Fakultas Kedokteran Universitas Malahayati \\ Universitas Malahayati
}

\section{Artikel info}

Artikel history:

Received; 16 Maret 2020

Revised:19 Maret 2020

Accepted;20 Maret 2020

\begin{abstract}
Abstrak
Latar Belakang: Penggunaan smartphone oleh mahasiswa dapat memberikan dampak yang positif dan negatif dalam proses pembelajaran. Dengan kemudahan dalam mendapatkan informasi dengan smartphone membuat mahasiswa termotivasi untuk mengikuti proses pembelajaran dikelas. berlangsung. Prestasi belajar dipengaruhi oleh karakteristik yang menunjukkan kepada faktor yang berasal dari dalam diri peserta didik, salah satunya adalah self-efficacy yang merujuk kepada keyakinan diri terhadap kemampuan yang dimilik. Metode: Desain penelitian ini menggunakan pendekatan analatik observasional dengan desain cross sectional. Teknik pengambilan sampel pada penelitian ini menggunakan metode purposive sampling dan didapatkan jumlah sampel sebanyak 118 orang. Analisis data menggunakan uji korelasi Spearman's. Hasil Penelitian: Hasil uji statistik bivariat korelasi Spearman's didapatkan masing-masing nilai $p$-value $=0,024$ pada kecanduan smartphone dan $p$-value $=0,000$ pada self-efficacy. Kesimpulan: Terdapat hubungan yang bermakna antara kecanduan smartphone dan self-eficacy dengan prestasi belajar pada mahasiswa Fakultas Kedokteran Universitas Malahayati angkatan 2018.

Abstract

Background: The use of smartphones by students have positive and negative impacts in the learning process. With the ease in obtaining information with smartphones makes students motivated to participate the learning process in class. Learning achievement is influenced by characteristics that indicate to the factors originating from within students, one of which is self-efficacy which refers to self-confidence in
\end{abstract}


the abilities possessed. Methods: The design of this study was observational analytic with cross sectional design. The sampling technique in this study used a purposive sampling method and obtained a total sample of 118 people. Data analysis used the Spearman trial test. Research Results: The result of Spearman correlation bivariate statistical test obtained that each $p$-value $=0.024$ in smartphone addiction and $p$-value $=0,000$ in self-efficacy.Conclusion: There is a significant relationship between smartphone addiction and self-efficacy with learning achievement of the students in Medical Faculty, University of Malahayati, class of 2018.

Keywords:

Kecanduan

smartphone;

self-efficacy;

prestasi belajar;
Coresponden author:

Email: betagustilawt@gmail.com

artikel dengan akses terbuka dibawah lisensi CC BY-4.0

\section{PENDAHULUAN}

Prestasi belajar adalah penguasaan seseorang terhadap pengetahuan atau keterampilan tertentu dalam suatu mata pelajaran, yang lazimnya diperoleh dari nilai tes atau angka yang diberikan dosen. Bila angka yang diberikan oleh dosen rendah, maka prestasi mahasiswa dianggap rendah. Bila angka yang diberikan oleh dosen tinggi, maka prestasi mahasiswa dianggap tinggi. Sekaligus dianggap sebagai seorang mahasiswa yang sukses dalam belajar Nasution (2016). Prestasi belajar di Malahayati di lihat dari Indeks Prestasi Komulatif (IPK). Menurut hasil data presurvey dari Medical Education Unit (MEU) di dapatkan pada Fakultas Kedokteran Universitas Malahayati angkatan 2018, tercatat 60 dari 168 responden masih memiliki IPK dibawah 2,76. Banyak faktor yang mempengaruhi prestasi belajar. Prestasi belajar siswa dipengaruhi oleh faktor eksternal dan internal (hazami,2017). Smartphone adalah telepon yang menyatukan kemampuan-kemampuan terdepan ini merupakan bentuk kemampuan dari Wireless Mobile Device (WMD) yang dapat berfungsi seperti sebuah komputer dengan menawarkan fitur-fitur seperti personal digital assistant (PDA), akses internet, email, dan Global Positioning System (GPS). Disamping itu, dalam tiga tahun dari tahun 2011-2014, persentase kepemilikan smartphone di kalangan orang dewasa di Amerika Serikat meningkat pesat dari 35\% menjadi 64\%, selanjutnya 15\% dari populasi warga Amerika Serikat berumur 18 dan 29 tahun terindikasi ketergantungan pada smartphone guna mengakses internet (Smith, 2015)

Kwon, Kim, Cho, dan Yang (2013) menyebutkan bahwa istilah kecanduan smartphone adalah perilaku keterikatan atau kecanduan terhadap smartphone yang memungkinkan menjadi masalah sosial seperti halnya menarik diri, dan kesulitan dalam performa aktivitas sehari-hari atau sebagai gangguan kontrol impuls terhadap diri seseorang. Penelitian lain yang dilakukan Demirci, Akgonul, dan Akpinar (2015) juga menyimpulkan bahwa penggunaan smartphone berlebihan dapat menyebabkan depresi dan kecemasan. Dikatakan mengalami kecanduan bila memiliki karakteristik seperti daily life disturbance, positive anticipation, withdrawal, cyberspace oriented relationship, overuse, dan tolerance (Kwon, 2013). Kecanduan smartphone belum muncul sebagai diagnosis dalam klasifikasi DSM(Diagnostic and Statistical Manual of Mental Disorders) V. Konsep kecanduan yang ada dalam DSM V masih terkait dengan kecanduan zat psikotropika. Dalam beberapa tahun 
terakhir telah terjadi kecenderungan untuk menggantikan kecanduan yang disebabkan oleh zat-zat, dengan perilaku kurangnya kontrol dan memberikan konsekuensi negatif. Contoh kecanduan tersebut adalah kecanduan judi, kecanduan gadget (mobile phone), kecanduan game, dan juga kecanduan internet (Starcevic, 2012).

Hasil penelitian Leung (2009) dengan subjek penelitian sebanyak 200 remaja yang berusia 17-18 tahun, didapatkan bahwa ada 4 gejala kecanduan telepon genggam antara lain inability to control craving (ketidakmampuan mengontrol keinginan menggunakan telepon genggam), anxiety and feeling lost (kecemasan dan merasa kehilangan bila tidak menggunakan telepon genggam), withdrawal and escape (menarik dan melarikan diri, artinya telepon genggam digunakan sebagai sarana untuk mengalihkan diri saat mengalami kesepian atau masalah), dan productivity loss (kehilangan produktivitas). Hasil survei science direct mengungkapkan sebanyak 25\% remaja di Asia mengalami nomophobia yaitu individu merasa cemas apabila berada jauh dari smartphone, sebanyak 72\% anak-anak menggunakan smartphone dengan durasi 4-5 jam per hari (Reza, 2015). Penelitian Tri Anasari (2014) kecanduan Smartphone pada remaja dapat menimbulkan dampak yang besar yakni sangat sulit membagi waktu, seperti tidak adanya waktu untuk belajar, mereka lebih focus terhadap smartphone yang dimiliknya. Penelitian Universitas Maryland (Herdiyanti, 2014) tentang kecanduan smartphone pada remaja menemukan bahwa remaja merasa cemas dan terkucilkan ketika tidak dapat menggunakan smartphone dalam satu hari. Menurut Chiu (2014) kecanduan terhadap smartphone merupakan salah satu bentuk untuk pengalihan rasa stres pada diri individu di kalangan remaja, karena tidak adanya kontrol diri yang kuat terhadap pemakaian smartphone.

Efikasi diri adalah keyakinan terhadap kemampuan yang dimiliki untuk dapat mengerjakan tugas, kuis, ataupun ujian yang diberikan, terkait dengan suatu materi pembelajaran (Holleb, 2016). Efikasi diri juga berpengaruh terhadap proses self regulation, keaktifan, dan psikologi mahasiswa dalam proses pembelajaran di perkuliahan (Stallings, 2011). Efikasi diri merupakan inisiator dan faktor penting terjadinya motivasi belajar, sehingga mampu mempengaruhi dilakukannya proses-proses yang mengarahkan pada keberhasilan dalam mendapatkan hasil belajar yang baik (Burgoon, 2008). Penelitian oleh Nurfitria (2009) menunjukkan bahwa efikasi diri memiliki hubungan yang positif dan signifikan terhadap hasil belajar pada siswa SMA PGRI 56 Ciputat. Tarmizi (2015) juga membuktikan adanya hubungan positif antara efikasi diri dan hasil belajar pada siswa kelas VII SMP Negeri 2 Seputih Mataram tahun pelajaran 2014/2015. Penelitian lain oleh Pertiwi (2015) pada siswa kelas V SD Daerah Binaan IV kecamatan Cilacap Selatan, didapatkan bahwa 29,6\% hasil belajar dipengaruhi oleh efikasi diri.

Mahasiswa Fakultas Kedokteran yang memiliki tingkat kecemasan tinggi, dan tugas-tugas yang banyak, akan sangat baik jika memiliki tingkat efikasi diri tinggi (Holleb, 2016). Namun ternyata, penelitian yang dilakukan oleh Henning et al. (2015) mengatakan bahwa tingkat efikasi diri mahasiswa kedokteran lebih rendah dibandingkan dengan siswa SMA Jerman dan pada populasi orang dewasa di Amerika. Gorji et al. (2015) juga melakukan sebuah penelitian pada Manzadaran University Of Medical Sciences dan hasilnya adalah bahwa tingkat efikasi diri mahasiswa Keperawatan dan Kebidanan lebih tinggi dibandingkan mahasiswa lainnya. Tingkat pendidikan juga memberikan sumbangsih terhadap tingkat efikasi diri yang dimiliki mahasiswa. Mahasiswa tingkat akhir memiliki efikasi diri yang lebih tinggi dibandingkan mahasiswa tingkat awal, hal ini dikarenakan mahasiswa tingkat akhir biasanya sudah mendapatkan ilmu pengetahuan dan pengalaman yang lebih banyak dibandingkan mahasiswa tingkat awal (Balloallo, 2010). 


\section{Metode}

Desain penelitian ini menggunakan pendekatan analatik observasional dengan desain cross sectional. Teknik pengambilan sampel pada penelitian ini menggunakan metode purposive sampling. Analisis data menggunakan uji korelasi Spearman's. Subjek penelitian ini adalah mahasiswa fakultas kedokteran Universitas Malahayati angkatan 2018 yang berjumlah 118 orang, prosedur penelitian dengan memberikan kuisioner dan melihat IPK semester dua responden, kuisioner yang digunakan ada dua yaitu kuisioner adiksi smartphone dan self efficacy.

\section{Hasil Dan Pembahasan}

Tabel 1. Analisis Uji Normalitas Hubungan Kecanduan Smartphone, Self Efficacy dengan Prestasi Belajar

Variabel Penelitian Jumlah Sampel P Value Signifikansi

\begin{tabular}{cccc}
\hline kecanduan smartphone & 118 & 0,000 & Tidak Normal \\
\hline self efficacy & 118 & 0,000 & Tidak Normal \\
\hline Hasil Prestasi Belajar & 118 & 0,000 & Tidak Normal \\
\hline
\end{tabular}

Tabel 2. Analisis Kecanduan Smartphone dengan Prestasi Belajar Pada Mahasiswa Fakultas Kedokteran Universitas Malahayati Angkatan 2018

\begin{tabular}{|c|c|c|c|c|}
\hline \multicolumn{5}{|c|}{ Correlations } \\
\hline & & & $\begin{array}{l}\text { kecanduan } \\
\text { smartphone }\end{array}$ & $\begin{array}{l}\text { Prestasi } \\
\text { Belajar }\end{array}$ \\
\hline \multirow[t]{6}{*}{ Spearman's } & \multirow{3}{*}{$\begin{array}{l}\text { kecanduan } \\
\text { smartphone }\end{array}$} & Correlation Coefficient & 1.000 & -.207 \\
\hline & & Sig. (2-tailed) & . & .024 \\
\hline & & $\mathrm{N}$ & 118 & 118 \\
\hline & \multirow{3}{*}{$\begin{array}{l}\text { Hasil Prestasi } \\
\text { Belajar }\end{array}$} & Correlation Coefficient & -.207 & 1.000 \\
\hline & & Sig. (2-tailed) & .024 & . \\
\hline & & $\mathrm{N}$ & 118 & 118 \\
\hline \multicolumn{5}{|c|}{$\begin{array}{l}\text { Tabel 3. Analisis Self Efficacy dengan Prestasi Belajar Pada Mahasiswa Fakultas } \\
\text { Kedokteran Universitas Malahayati Angkatan } 2018\end{array}$} \\
\hline \multicolumn{5}{|c|}{ Correlations } \\
\hline & & & self efficacy & $\begin{array}{l}\text { Isil Prestasi } \\
\text { Belajar }\end{array}$ \\
\hline \multirow[t]{6}{*}{ Spearman's } & self efficacy & Correlation Coefficient & 1.000 & .432 \\
\hline & & Sig. (2-tailed) & & .0 .000 \\
\hline & & $\mathrm{N}$ & 118 & 118 \\
\hline & \multirow{3}{*}{$\begin{array}{l}\text { Hasil Prestasi } \\
\text { Belajar }\end{array}$} & Correlation Coefficient & .432 & 1.000 \\
\hline & & Sig. (2-tailed) & .000 & . \\
\hline & & $\mathrm{N}$ & 118 & 118 \\
\hline
\end{tabular}

Hubungan Tingkat Kecanduan smartphone dengan Prestasi Belajar 
Hasil analisis antara kecanduan smartphone dengan prestasi belajar dengan nilai p-value $=0,024$. Hal ini menunjukkan bahwa ada korelasi antara kecanduan smartphone dengan prestasi belajar dengan diperoleh nilai korelasi sebesar -0,207. Nilai ini menunjukkan korelasi antara kecanduan smartphone dengan prestasi belajar pada penelitian ini adalah rendah dan bernilai negatif, yang artinya semakin tinggi tingkat kecanduan smartphone semakin menurunkan prestasi belajar mahasiswa. Hasil penelitian yang dilakukan oleh Beauty (2015) menunjukkan adanya hubungan penggunaan Gadget dengan tingkat prestasi siswa $(\mathrm{p}=0,016)$. Sejalan dengan penelitian Arif (2017) menunjukkan ada hubungan negatif antara intensitas penggunaan smartphone dengan prestasi akademik $(p=0,001)$. Kehadiran dari smartphone ini memang mampu memberi berbagai manfaat dan kemudahan bagi penggunanya, khususnya bagi mahasiswa, dimana fasilitas-fasilitas yang terdapat dalam smartphone tidak hanya terbatas pada fungsi telepon dan sms saja melainkan dapat digunakan sebagai sarana pembelajaran dimana melalui smartphone seseorang dapat mempelajari hal-hal baru melalui isi atau pesan yang disalurkan Daeng (2017).

Kleden (2016) juga mengungkapkan penggunaan smartphone untuk mencari informasi pembelajaran dapat membantu dan memaksimalkan nilai yang didapat. Namun penggunaan smartphone juga memiliki dampak negatif jika digunakan ketika kegiatan perkuliahan sedang berlangsung, karena kecenderungan penggunaanya lebih kepada penggunaan yang kurang terkait dengan kegiatan perkuliahan. Oktario (2017) menjelaskan bahwa seseorang yang seharusnya dapat memaksimalkan waktunya untuk belajar dan berusaha dalam proses pembelajaran, namun lebih memilih untuk menggunakan smartphone untuk hal yang tidak terkait dengan pembelajaran dan penggunaan yang kurang tepat dengan intensitas yang tinggi maka akan berdampak pada menurunnya motivasi berprestasi yang berakibat pada menurunya prestasi akademis. Menurut Oktario (2017) penggunaan smartphone memiliki dampak yang positif dan negatif. Salah satu dampak positif dari penggunaan smartphone yakni memudahkan mencari informasi dan menjadi jembatan kepada dunia luar. sedangkan dampak negatif dari penggunaan smartphone yaitu dengan berbagai aplikasi seperti penggunaan media sosial, menonton video dari internet, bermain games dan aplikasi lainya yang penggunaanya tidak terbatas bahkan ketika proses pembelajaran sedang berlangsung.

Menurut Sarwar, Soomro, Traiq (2013) dalam dunia pendidikan dampak penggunaan smartphone yaitu kemudahan dan efisiensi dalam mencari suatu informasi yang diperlukan sehingga memicu pelajar untuk sering menggunakannya. Rahma (2015) juga menyebutkan bahwa dampak positif daripenggunaan smartphone bagi pelajar adalah mempermudah mereka dalam belajar. Kemudahan yang didapatkan melalui penggunaan smartphone dalam mencari informasi-informasi ini akan mempengaruhi motivasi belajar mahasiswa, dimana menurut Syamsu Yusuf (2009) fasilitas belajar berupa sarana dan prasarana adalah salah satu faktor yang mempengaruhi motivasi belajar.

\section{Hubungan Self Efficacy dengan Prestasi Belajar}

Hasil analisis antara self efficacy dengan hasil prestasi belajar dengan nilai $p$-value $=0.000$. Hal ini menunjukkan bahwa ada korelasi antara self efficacy dengan hasil prestasi belajar dan juga menampilkan nilai korelasi data yaitu 0.432. Nilai ini menunjukkan korelasi antara self efficacy dengan hasil prestasi belajar pada penelitian ini adalah sedang dan bernilai positif, yang artinya semakin tinggi self efficacy semakin baik hasil prestasi belajar mahasiswa. Hasil penelitian di atas sejalan dengan penelitian yang dilakukan oleh Mahyuddin (2006), yang berjudul The Relationship Between Students Self Efficacy and 
Their English Language Achievement, menghasilkan bahwa terdapat hubungan yang positif antara self efficacy dengan prestasi belajar bahasa inggris pada 1.146 siswa di Malaysia. Selain itu, penelitian yang dilakukan oleh Warsito (2009), Hubungan antara Self Efficacy dengan Penyesuaian Akademik dan Prestasi Akademik, yang juga menghasilkan bahwa ada hubungan antara self efficacy dengan prestasi akademik pada 130 mahasiwa Fakultas Ilmu Pendidikan Universitas Negeri Surabaya.

Menurut Bandura (1997) self efficacy merupakan hasil dari proses kognitif berupa keputusan, keyakinan, atau penghargaan tentang sejauh mana individu memberikan kemampuan dirinya dalam melaksanakan tugas dan tindakan tertentu yang diperlukan untuk mencapai hasil yang di inginkan. Menurut Winkel (2014) prestasi belajar adalah keberhasilan usaha dan gambaran kemampuan seseorang yang dicapai seseorang setelah memperoleh pengalaman belajar atau sesuatu. Mahasiswa yang memiliki prestasi belajar tinggi dalam mata kuliah adalah mahasiswa yang memiliki usaha, kemampuan yang tinggi untuk dapat menguasai, dan memiliki pengalaman dan persepsi yang positif terhadap pelajaran. Demikian sebaliknya, mahasiswa yang memiliki prestasi belajar rendah adalah mahasiswa yang kurang memiliki usaha, kemampuan yang rendah untuk dapat menguasai pelajaran , memiliki pengalaman dan persepsi yang negatif terhadap pelajaran, dan memiliki keyakinan rendah terhadap kemampuannya untuk mencapai skor yang tinggi, mahasiswa yang merasa pesimis dengan kemampuanbelajar, bahkan menghindari untuk mengulang mata kuliah yang di sebabkan oleh ketidakyakinan untuk bisa lulus dalam mata kuliah. Hal ini sejalan dengan yang dikatakan Shunk (Santrock,2009) bahwa mahasiswa yang menghindari tuntutan tugas yang menantang adalah mahasiswa yang memiliki self efficacy rendah dalam mempelajari mata pelajarannya. Dan seperti yang dikatakan Santrock (2009) bahwa mahasiswa yang memiliki ekspektasi yang rendah pasti akan berprestasi rendah. Dengan demikian dapat dikatakan bahwa mahasiswa yang memiliki prestasi belajar rendah pada mata kuliah adalah mahasiswa yang memiliki keyakinan rendah terhadap kemampuannya (self efficacy rendah).

\section{Simpulan Dan Saran}

Ada korelasi antara kecanduan smartphone dengan hasil prestasi belajar dengan diperoleh nilai $p$-value $=0.024$ dan nilai korelasi sebesar -0.207 . Nilai ini menunjukkan korelasi antara kecanduan smartphone dengan hasil prestasi belajar pada penelitian ini adalah rendah dan bernilai negatif, yang artinya semakin tinggi tingkat kecanduan smartphone semakin menurunkan hasil prestasi belajar mahasiswa. Ada korelasi antara self efficacy dengan hasil prestasi belajar dengan diperoleh nilai $p$-value $=0.000$ dan nilai korelasi sebesar 0.432. Nilai ini menunjukkan korelasi antara self efficacy dengan hasil prestasi belajar pada penelitian ini adalah sedang dan bernilai positif, yang artinya semakin tinggi self efficacy semakin baik hasil prestasi belajar mahasiswa.

Diharapkan institusi dapat menjadikan smartphone sebagai media pembelajaran online untuk menunjang proses pembelajaran mahasiswa Fakultas Kedokteran Universitas Malahayati. Diharapkan untuk mahasiswa Fakultas Kedokteran Universitas Malahayati dapat menggunakan smartphone secara bijak untuk menunjang proses pembelajaran seperti mencari jurnal, membuka e-book, dll. Diharapkan untuk peneliti selanjutnya dapat mengembangkan penelitian ini dengan metode penelitian kuantitatif dan serta dapat menambahkan variabel-variabel yang lain. Hasil penelitian ini dapat digunakan sebagai informasi atau penyuluhan mengenai hubungan tingkat kecanduan smartphone dan self efficacy dengan prestasi belajar. Selain itu, dapat diaplikasikan oleh responden di dalam kehidupan pribadi. 


\section{Daftar Rujukan}

Pinasti, D. A., \& Kustanti, E. R. (2017). Hubungan Antara Empati Dengan Adiksi Smartphone Pada Mahasiswa Fakultas Ilmu Budaya Dan Fakultas Sains Dan Matematika Universitas Diponegoro Semarang. Empati, 6(3), 183-188.

Mailina, W. R., Zulharman, Z., \& Asni, E. (2015). Hubungan Efikasi Diri dengan Nilai Objective Structured Clinical Examination (Osce) pada Mahasiswa Tahun Ketiga Fakultas Kedokteran Universitas Riau. Jurnal Online Mahasiswa Fakultas Kedokteran Universitas Riau, 2(2), 1-10. Retrieved from https://www.neliti.com/id/publications/187591/hubungan-efikasi-diri-dengannilai-objective-structured-clinical-examination-osc

Masruroh, S., Saputra, O., Oktaria, D., Utami, N., Kedokteran, F., Lampung, U., ... Lampung, U. (2019). Hubungan Efikasi Diri terhadap Hasil Belajar Blok Emergency Medicine pada Mahasiswa Tingkat Akhir Fakultas Kedokteran Universitas The Relationship between Self Efficacy and Learning Outcome in Emergency Medicine Block of Final Year Medical Students in Med, 6, 20-24.

Rozalia, M. F. (2017). Hubungan Intensitas Pemanfaatan Gadget Dengan. Jurnal Pemikiran Dan Pengembangan SD, 5(2), 722-731.

Erizka, R., Nadjmir, \& Usman, E. (2016). Hubungan Kejadian Internet Addiction dengan Prestasi Belajar pada Mahasiswa FK Unand. Jurnal Kesehatan Andalas, 5(3), 625629. Retrieved from http://jurnal.fk.unand.ac.id/index.php/ika/article/viewFile/588/476

Hasanah, U., Maria, S., Lutfianawati, D., Kedokteran, P. S., Studi, P., Universitas, P., ... Malahayati, U. (2016). Hubungan Regulasi Diri Dalam Belajar Dengan Prestasi Belajar Pada Mahasiswa Angkatan 2016 Fakultas. Jurnal Psikologi, 78-87.

Siswa, B., Tahun, U., Arifin, L. A., \& Rahmadi, F. A. (2017). Hubungan Tingkat Kecanduan Gadget Dengan Prestasi Belajar Siswa Usia 10 - 11 Tahun. Jurnal Kedokteran Diponegoro, 6(2), 728-736.

Indawati, E., Apriano, R., Studi, P., Keperawatan, S., Abdi, S., Jakarta, N., \& Kunci, K. (2018). Tujuan dari penelitian ini adalah untuk mengidentifikasi hubungan antara Intensitas penggunaan Smartphone dengan Prestasi akademik (IPK) mahasiswa di STIkes Abdi Nusantara Jakarta, (3), 100-106. 